\title{
How electoral integrity affects voter turnout in democracies
}

\begin{abstract}
Does electoral integrity affect turnout? And if so, how? We analysed some variables that are closely related to electoral integrity - government actions, opposition actions, and the context in which the election is held - and find significant impact on turnout. We argue that higher turnout is often found in elections with higher electoral integrity. We test our claims using data for over 700 elections covering 85 democracies for the 1950-2008 period. Results reveal that both boycott and election-related violence decrease turnout, but the effect of the former is substantially higher. We also find that, contrary to initial expectations, governments' harassment of the opposition and the occasional banning of parties actually increases turnout.
\end{abstract}

Keywords: electoral integrity, turnout, boycott, election protest, election violence 


\section{Introduction}

When the polls for the Senegalese parliamentary elections of June 2007 closed, ballot counts showed a turnout of 35 per cent (Galvan 2009). Five months earlier, 70 per cent of Senegalese voters had voted in the presidential elections. If turnout can provide any insight on democratic legitimacy, the two elections must have differed sharply in this regard. The difference in election type does not justify a difference of 35 percentage points. Few other things differed between these two elections, except for an election boycott in which 17 opposition parties called to protest the government's handling of the parliamentary election. That a single action could deliver such significant impact justifies the study of the conditions surrounding elections and their impacts on participation. This paper highlights that all else equal, when elections are characterised by electoral integrity, turnout increases. Electoral integrity is defined as whether elections meet international standards, as established through conventions, treaties, and guidelines, at all stages of the electoral cycle from the pre-election period through the campaign to polling day and its aftermath. It is conceptually diametric to electoral malpractices, which reflect the failure of these contests to meet international standards (Norris 2014) ${ }^{1}$. Evidence for this claim lies within the dynamics of the election, namely what happens before, during, and after it. Certain dynamics, for instance boycotts or protests, are often evident of integrity violation, and when they occur turnout figures drop.

Previous research, -see Birch (2010), Simpser (2012) or Carreras and Irepoglu (2013)- have showed that, when polls are flawed, citizens have less incentive to cast their votes. All these works, however, have a limited scope. Birch (2010) and Carreras and Irepoglu (2013) did not consider fully whether the perceptions of the citizens are affected by the conditions in which the election is held, and their analysis left out countries where the highest levels of electoral malpractice are observed (mainly African and Asian countries). Simpser (2012) overcame the former problem by showing how electoral manipulation by the Institutional Revolutionary Party (PRI) discouraged Mexicans from turning out to vote by establishing a concrete link between reality and perception. His analysis limits to Mexico and its electoral reforms in the 1990s. Consequently, generalisability lingers and requires a comprehensive and generalisable account at the aggregate level.

\footnotetext{
${ }^{1}$ We understand electoral integrity as Norris (2014), but we use it to focus on the actions of the government, the opposition and the context in which those take place.
} 
This paper analyses a) whether electoral integrity affects turnout and b) the ways in which it affects turnout. We make three major contributions. First, we combine two currently distinct research agenda on electoral integrity and turnout. In particular, we look at the three dynamics through which violation of electoral integrity is often reflected: the actions of the incumbent, the actions of the opposition and, the environment in which those actions take place. Second, we introduce a large and comprehensive dataset with over 717 elections in 85 countries worldwide covering the 1950-2008 period. The dataset comprises the standard variables of turnout as well as reliable proxies for electoral integrity: for each of the aforementioned dynamics, we look at a number of illustrative salient variables. Finally, results confirm the importance of electoral integrity for turnout: where election dynamics reflect a lack of integrity, turnout does not stay constant: opposition harassment and the occasional banning of certain political parties corresponds to an increase in turnout, while boycott and violence decreases it.

This paper also offers significant theoretical advancement,. Recent years have witnessed the advancement of the discipline with a series of studies on the factors impacting turnout at the aggregate level (see Stockemer et al (2013); Solt (2008); or Steiner (2010) among others). In that regard, this article is among this group. Furthermore, we provide a complement to Norris (2014) measure of electoral integrity. Our work has also evident policy implications: by including specific election dynamics that may affect turnout, this paper is of key importance to the policy and practitioner community when assessing the reasons for turnout differences.

The second section explains how different dimensions of integrity-related dynamics are expected to affect turnout. The third section presents the dataset and describes the crossnational coverage as well as the variables and research design. The fourth section presents the results and the conclusion considers their implications.

\section{Turnout and electoral integrity}


There are three reasons to include electoral integrity into the analysis of turnout. First, according to Pastor, 'democracy should be more than free and fair elections, but it cannot be less' (1998: 154). Electoral integrity therefore should be considered: if elections are key for democracies, it is not logical to exclude the qualities of these elections.

Second, the link between electoral integrity and turnout is fundamental for the legitimacy of democracies: if the lack of electoral integrity damages legitimacy, it should be expected to have an impact on turnout. The relationship between legitimacy and turnout has long been established (Norris 2011) but, the confidence on the electoral process itself has been out of the equation (Birch 2010). As electoral integrity is linked with legitimacy, it should be expected to have a positive impact on turnout. Its absence from the analysis may then lead to an incomplete account not only of turnout, but also of political legitimacy.

The final reason to include electoral integrity is its evident role at other levels of analysis. Birch (2010) offered an explanation of how the lack of electoral integrity negatively affects individuals' decision to vote. Her logic is straightforward: citizens will turn out to vote if they perceive that their vote will be counted fairly. She proposed that vote calculus models must include the perceived probability that the elections will be conducted fairly: the voter will first calculate whether her vote will be processed reliably and, only then, will decide about turning out to vote. These results are in accordance with findings by Alvarez et al (2008) for the United States. Given the evidence of electoral integrity's impact at the individual level, a study to test its generalisability becomes indispensable.

Similarly, electoral integrity has been present in the explanation of turnout in country specific studies. For instance, Simpser (2012) in a study of the 32 Mexican states explained the changes in turnout before and after the reforms introduced in the 1990s. He found that 'each percentage point of the vote that the PRI added to its total via manipulation in the pre-reform period was associated with a 1.7 [per cent] to 2.4 [per cent] decrease in the pre-reform level of (true) turnout' (2012: 793). His findings are in accordance with McCann and Dominguez (1998) who also found that in Mexico, 'the greater the expectation of fraud, the lower the 
likelihood of voting' (499). Insightful and detailed these studies were, their results still suffer from some generalisability problem.

We only focus on democracies because the available literature's incomplete theoretical understanding of voting behaviours in non-democracies, as well as the general unreliability of turnout statistics in many of these regimes. Moreover, as Martinez i Coma shows (2016), determinants of turnout in democracies are different from those in non-democracies.

Finally, a study that focuses on democracies enjoys the benefits of established theories and reliable statistics, and yet still addresses several interesting questions. Even in democracies, electoral integrity and voter turnout exhibit wide variation. Electoral integrity varies widely among democracies. While many may believe otherwise, democracy and electoral integrity are separate concepts. Granted, democracies are often conceived of as political systems under which free and fair elections are held. At the same time, however, even under these systems what is understood by free and fair vary wildly. Even in established democracies, elections and their integrity are still the focus of significant controversy, with debates on difficult questions such as campaign finance or gerrymandering. Like electoral integrity, voter turnout exhibits great variation: in 2012 alone, it ranged from just above 50 per cent in the United States to nearly 91 per cent in Bahamas (IDEA 2014). If participation is indeed the core of democracy, this variation immediately dismisses any assumption of democratic homogeneity. Given the variation in electoral integrity in democracies, a study marrying turnout and electoral integrity in this context is definitely of significant value.

\section{How does electoral integrity affect turnout?}

Electoral integrity is a multidimensional concept. Thus, not all of its dimensions 'may matter equally for voter turnout' (Norris 2014: 135). Electoral integrity is also difficult to measure (Schedler 2012). To overcome this problem, Norris (2014) relies on the Perceptions of Electoral Integrity Index (an aggregate measured composed by 49 indicators based on 
experts' views on elections). Instead, we use election dynamics as proxy measures, selecting observed dynamics that we considered to be closely linked to electoral integrity ${ }^{2}$.

In this paper, we looked at three particular dimensions: actions by the two main actors, the government and the opposition, and the context in which these actions take place. Within each of these dimensions we picked out dynamics that indicate the gravest threat to electoral integrity and focused on explaining their influences on turnout.

\section{Government actions}

The first dimension of election dynamics is government actions. Even in democracies, governments retain the power to influence the level of political competition in an election (Schedler 2002). Such power has significant bearing on electoral integrity, considering how competition is a fundamental and indispensable aspect of elections. The first and most extreme way governments had exercised this power is to shut down entirely competition from one or more parties. Banning of opposition parties is not exclusively used by dictators, and also takes place in democracies. For example, in 1988 the Israeli court banned the Kach party from competing on the ground that it was racist and undemocratic (Pedahzur and Perliger 2004). In Spain, the Political Parties Organic Law (Organic Law 6/2002, 27 $7^{\text {th }}$ of June) led to the banning of Batasuna from competing in the general elections of 2004 because of ties with the terrorist group ETA. The banning continued after the European Court of Human Rights in $2009^{3}$ (25803/04 and 25817/04) ruled in favour of the law.

Banning opposition parties has direct implications for electoral integrity. If the ban is not legally justified, it is by itself a violation of integrity. In other cases, a decision to ban may reveal underlying problems with integrity (e.g. Uzbekistan in 2007 banning Birlik, Erk and

\footnotetext{
${ }^{2}$ Furthermore, with our conceptualization we can go back in time while Norris' measure starts in 2012.

${ }^{3}$ European Court of Human Rights (2009) Affaires Herri Batasuna et Batasuna c. Espagne. Requetes n 25803/04 et 25817/04.
} 
Ozod Dehkon (OSCE 2007). Banning political parties matters for turnout because it may reduce the degree of competition. Indeed, in the literature on political systems, the number of parties has been frequently used as a proxy for competition (Blais and Carty 1990), which is also found to be linked with turnout (Blais and Dobrzynska 1998). If the banning of opposition parties does reduce competition, then it would be expected to have a negative impact on turnout. At the same time, when the bans can be perceived as falling within democratic standards, their impact on political competition and turnout may be minimal. Therefore, although banning opposition parties generally reduce competition and hence turnout, it is not a common behaviour in democracies and there are plenty of exceptions in which this may not hold. Including this variable in the analysis would allow for a concrete insight into whether it matters at a general level. ${ }^{4}$

Governments may still reduce competition through a second measure: by making it harder for the opposition to compete. Similar to banning political parties, in most cases harassment is by itself a violation of electoral integrity, and can have an impact on turnout. Donno and Roussias (2012) showed how pre-election misconduct towards opposition parties not only affects these parties but 'may also deter voters from casting ballots for the opposition or expressing their support during the campaign'. The reason is that harassment changes the perception of competition, making citizens conceive of elections as futile (2012: 580). Their work was tested on 166 elections in Latin America and post-communist countries between 1990 and 2004, but misconduct towards opposition parties do also take place in other regions such as Africa or Asia. An example for Africa would be the 2013 election in Benin, when both main parties alleged intimidation, while the 2001 Filipino election, when former president Estrada was arrested on TV, serves as an example for Asia. If their theory does indeed travel beyond Latin America, Donno and Roussias's (2012) reasoning would lead us to expect a negative relationship between harassment and turnout at the aggregate level.

\footnotetext{
${ }^{4}$ We do note that, ideally, a measure of the banned party’s influence would allow for a much more nuanced analysis, as it can be expected that banning a major party would leave much greater impact than banning a small, marginal party. Empirical and conceptual challenges, however, prevented us from including such measure. Empirically, data on party size is not available reliably for our sample of interest. Furthermore, even if data is available, conceptualizing party influence remains a difficult challenge, as common measures such as number of seats are often not flexible enough to measure actual influence of parties from different political systems. For instance, fringe parties in fragmented parliamentary system may command disproportionately strong influence if they hold the deciding seats for a coalition.
} 
Simultaneously, however, harassment by the government can simply be an indicator of political competition: when stakes are high and the race is close, the government is more inclined to turn to aggressive strategies to defeat their opposition. Moreover, outside of Latin America and post-communist countries, harassment may not be severe enough to have a significant impact on people's voting decision. For example, in the 1992 South Korean election, despite Hyundai founder and presidential candidate Chung Ju-yung being subjected to interrogation and his company to government audit, turnout still reached 85 per cent (Kang 1998). In this case, while violation of electoral integrity is evident, the effect on turnout may not be as pronounced. For this reason, an analysis at the aggregate level is needed before the effect of harassment on turnout can be conclusively determined.

\section{Opposition actions}

Turnout can also be a function of opposition parties' behaviours (Lindberg 2006; Schedler 2002), many of which are integral to electoral integrity. Election boycotts have been one of the most analysed measures, rightly so because they are an extreme measure that sends a strong statement and attracts attention. Election boycotts can be both an indicator of integrity violation and an act of violation itself. Most often, boycotts are used to protest (Schedler 2002) and in this capacity they reveal problems with the election. In Jamaica, in 1983, an election was called unexpectedly following a political quarrel between the governing Jamaican Labour Party (JLP) and the opposition Peoples' National Party (PNP). PNP invoked a prior agreement with the JLP, which required the creation of a new registry of voters before a new election would be called. After JLP rejected the call, PNP argued further that about 100,000 voters were disenfranchised, and proceeded to boycott the election despite polls showing reasonable chances of winning. Left as the only running party, JLP won all 60 seats of the House.

Simultaneously, a boycott is not simply a symptom of a flawed election. As Lindberg stated (2006), even when elections are legitimate, the opposition can strategically boycott because its winning chances are slim. Consider the 2008 Ghanaian elections. When faced with unfavourable results in the first round, the governing New Patriotic Front (NPP) called for a 
delay of the second round. When the courts reject this call, NPP agents 'toured towns and villages in the district on Thursday night urging supporters to boycott the vote' (BBC 2009). In the end, the NPP still lost the election (Kofie Daddieh 2009).

In both cases, it is logical to expect opposition boycott to reduce turnout significantly. Firstly, the turnout figure will not include supporters of the boycotting party. Secondly, supporters of the governing party, having had the security of decreased competition, may not feel the necessity to vote. Lastly, when a boycott draws attention to the flaws of an election, it may induce even neutral voters to harbor doubts and stay home.

Context of the election

Actions taken by the government and the opposition do not happen in a vacuum. They can be all influenced and conditioned by the most encompassing dimension of electoral integrity: first-order problems (Norris 2014), which include deadly violence or major violations of fundamental human rights. Violence in particular violates electoral integrity but can also be the causes or products of other forms of violations.

The impact is straightforward: violence creates an atmosphere of insecurity and deters voters from showing up. The evidence points to a negative correlation between electoral violence and turnout, although it is not conclusive. On the one hand, Kuhn (2013), in a study of SubSaharan African countries, found that 'citizens fearing victimisation during election campaigns are significantly less likely to vote'. His findings are consistent with other cases such as Nigeria (Collier and Vicente 2014) or Colombia (García 2009). Trelles and Carreras (2012) found that criminal violence in Mexican municipalities, most of which drug related, negatively affects turnout. On the other hand, some violence, in particular terrorism, can lead to anxiety in the electorate whom, as a reaction, would increase their attention to salient and proximate political events such as an election, as argued by Robbins et al (2013). Indeed, the authors' empirical study of 51 democracies found a positive relationship between terrorism 
and turnout. With the impact of violence on turnout being able to go both ways, it is interesting to include them in an aggregate analysis to determine which direction prevails.

Overall, we posit four election dynamics closely linked to electoral integrity: banning of opposition parties, harassing opposition, election boycotting, and the presence of violence during the election. While they are not the only factors influencing turnout, all of them stand out as strong proxies for electoral integrity, and thus are essential for the understanding of 'free and fair' elections. Based on our arguments, we hypothesise that all of them can potentially reduce turnout, with the effect of opposition banning less clear due to the possibility of legitimate and legal bans having no effect on voters' perception of electoral integrity.

To test this hypothesis, we propose a minimal model in which turnout depends on, among other factors, the integrity of the election. To measure electoral integrity, we group the four aforementioned dynamics along three dimensions: government actions, opposition actions, and the context in which elections are held. Under government actions, we look into banning of opposition parties and opposition harassment, which we believe to have a non-zero effect but are unsure about the direction. Under opposition actions, we focus on boycotts and hypothesise a negative impact. The same applies for violence, which goes under the context of the election. We admit that our model does not capture all the actors nor all the elements present in the context. We do contend, however, that the selected dimensions and variables are the minimum that should be present in the analysis when explaining turnout.

\section{Data, variables and methods}

Our dependent variable is turnout rate, for which definitions vary. Most studies use the number of valid votes cast as the numerator. They differ wildly, however, in the choice of denominator: voting age population, number of eligible voters, number of registered or the size of the electorate. We define turnout as the number of votes cast divided by the voting age population, which is the most common in the literature. 
We obtain the dependent variable from the works of Nohlen and associates and also check with the data from Institute for Democracy and Electoral Assistance (IDEA) website on voter turnout. The correlation between both sources is 0.96. The data is presented country by country and differentiates between registered voters as well as voting age population. Unlike many other studies, we include both executive and legislative elections in our dataset, believing that they share most common determinants. Our dependent variable is composed of elections occurring in the 1950-2008 period in 85 democracies.

Data for the independent variables come from multiple sources, but mostly from two main datasets. The first dataset is compiled by The Quality of Governance (QoG) Institute at the University of Gothenburg (Teorell et al 2013). Their Standard Dataset 2013 is a crosssectional time-series dataset with global coverage spanning the time period 1946-2012. Since QoG contains multiple data series with different coverage for some measures, for instance GDP, it allows us to combine these series to expand our data coverage. The second dataset, the National Elections Across Democracy and Autocracy (NELDA), is developed by Susan Hyde and Nicolay Marinov (2012) covering all states with a population above half a million in existence for any period between 1945 and 2012 are included, since we have used version 4. We also use NELDA’s 2013 expansion by Hyde et al (2014).

Independent variables measuring electoral dynamics come entirely from NELDA dataset. To measure the effect of government's banning of opposition leaders, we use NELDA13 variable, which asks whether opposition leaders were prevented from running. For harassment, we use NELDA15, which asks whether there is evidence that the government harassed the opposition. To measure opposition's behaviour, NELDA14, which asks whether some opposition leaders boycott the election, is used to indicate instances of boycotting.

In regard to violence, we use NELDA33, which asks whether there was any significant violence involving civilian deaths immediately before, during, or after the election. Regrettably, this variable does not differentiate between pre-election and post-election 
violence. ${ }^{5}$ It is still reasonable to assume, however, that, even in cases where violence broke out after the election, the tension must have existed prior to the election day and contributed to deterring voters from turning out to vote. The correlation among all NELDA variables is below 0.34 and all are dichotomous.

In addition, we include the common control variables. These variables have been classified as socio-economic, institutional or political (Blais and Dobrzynska 1998; Geys 2006). For the socio-economic variables we include the log of the population, the log of GDP, and a measure of population heterogeneity. It has been stated that the effect of population size is negatively correlated with turnout (Blais and Dobrzynska 1998; Blais and Carty 1990), while economic development seems to increase turnout (Blais and Dobrzynska 1998). The evidence on the effect of population heterogeneity on turnout is not conclusive (Geys 2006:643-644). Previous turnout has been found to significantly impact turnout (Aldrich et al. 2011), but as this variable tends to soak up the explaining power of relatively time-invariant variables such as institutions or population (Achen 2001), we reserve it for the robustness check. We also do not include the level of democracy because common graded measures of democracy such as Freedom House or Polity IV often already include aspects of electoral integrity in their definitions. In the literature on turnout, Blais and Drzobinska (1998) is perhaps the only one to include this variable, but only as a proxy for free and fair elections. Since we are getting at the questions of free and fair elections even more deeply, we do not see the need to follow their procedure.

Data for these controls come from the QoG dataset. For population size, we combine five different series - Maddison (Bolt and van Zanden 2013), Gleditsch (2002), Penn’s World Tables, World Development Indicators (WDI), and United Nations - to maximise available data. Similarly, we combine the Maddison (Bolt and van Zanden 2013), Gleditsch (2002) and WDI series and took the log of this combined measure to account for GDP. Data for

\footnotetext{
${ }^{5}$ It is worth noting that we did attempt to code instances of pre-election violence separately from post-election violence using NELDA15 in conjunction with NELDA33 following Hafner-Burton, et al's (2014) coding scheme. Although we managed to produce a measure that is in complete agreement with their variable for all the cases included in their replication data, we are not confident that this coding scheme would correctly differentiate between the two periods of violence.
} 
population heterogeneity comes from the measure of ethnic fractionalisation by Alesina et al. (2003).

To account for the institutional explanations, we look at compulsory voting, election type and electoral formula. The importance of compulsory voting is one of the most solid findings in the literature: when voting is compulsory, turnout is higher (Blais 2006). We also differentiate between whether the election was parliamentary or presidential. For both cases, data comes from International IDEA. Proportional systems seem to have a positive impact on turnout when compared with mixed or majoritarian (Blais and Dobrzynska 1998). Also following Blais and Dobrzynska (1998) we include the concurrency of elections, which they use as a proxy for the decisiveness of the elections and expecting higher turnout in more decisive elections. To account for the electoral formula, we use an indicator for proportional system, which is known for leading to higher turnout (Blais and Dobrzynska 1998: 248). This indicator comes from Golder (2005).

We include two political variables: the first measures the degree of competitiveness in the election measured as the distance between the first and second parties or candidates. The logic is that the more competitive the election is, the higher the turnout. The second variable is an indicator for whether the office of the incumbent was being contested in the election. The assumption is that turnout will be higher if this is the case. The logic is as follows: if the office of the incumbent is being contested voters have the opportunity to reward or punish their party’s performance, which may drive turnout upward. Data for this variable came from NELDA20 variable, which asks whether the incumbent's office is being contested in the election. According to Hafner-Burton et al. (2014), this variable takes into account also parliamentary election and is thus more appropriate than NELDA21, which simply asks whether the incumbent is running. Table $\mathrm{A}$ in the appendix presents a description of the variables used in the analysis.

\section{Estimation procedure}


To estimate the effect of the electoral integrity on turnout, we run several linear regressions. Our model employs panel-corrected standard errors, which we further correct for panelspecific autocorrelation. In this way it manages to account for both time-serial dependencies and within-panel correlated error terms.

As mentioned, we consider adding a one-year lag of the dependent variable, but decide against including it in the main model. The reason is that while this lagged variable is theoretically valid it can absorb the explaining power of other equally theoretically valid variables that are more time-variant, such as institutions or population parameters (Achen 2001). We do, however, include it in our robustness check and found very similar results.

\section{Results}

As can be seen from Table 1, all three aspects of electoral integrity are found to have significant impact on turnout. In this table, model 1 touches on the government's actions, model 2 on the oppositions', while model 3 considers the environment in which the election takes place. Finally, model 4 includes all the components jointly.

\section{[TABLE 1 ABOUT HERE]}

Regarding government actions, the results show clear support for our hypotheses. To begin with, banning opposition parties does appear to have a positive impact on turnout. We suspect that this is because for the democracies in our sample whenever bans are put in place they are often legitimate in the eyes of the electorate. Very different results may have been found if our analyses been had done for autocracies.

In the same line as banning opposition parties, results show that elections where harassment of opposition occurred often see higher turnout. This casts doubt on Donno and Roussias's (2012) hypothesis. As we argued earlier, in democracies, harassment by the government may 
be an indicator of highly contested elections that are likely to see high turnout. Also, legal and political constraints in democracies mean that government harassment may never get serious enough to deter voters from turning out to vote.

This counterintuitive finding may have some serious implication depending on which side benefited from the increased turnout. Tentative comparison of means suggests that the opposition is 20 percentage points less likely to make gains when they are harassed, suggesting that perhaps the increased turnout does not work in their favour. This finding, however, should not be taken as conclusive, given that potential confounders prevent a proper causal treatment of the link between opposition harassment, turnout and their performance. Even an instrumental variable approach would not yield satisfactory result as opposition harassment is far from exogenous to this relationship.

In terms of opposition actions, the impact of boycotts is negative, and is very pronounced, robust and clear. As can be seen in models 2 and 4, elections where some opposition parties or leaders decide to boycott see significantly lower turnouts, close to 7 percentage points. This result is consistent with our hypothesis. It also bears important political implications for the opposition parties and incumbents when faced with the possibility of a boycott: an average decline of 7 percentage points may have only nominal consequences for established democracies but, in younger democracies, this could present a serious threat to the legitimacy of the regime.

When considering the context of the election, violence negatively impacts turnout, a finding consistent with previous literature and with our hypothesis. The magnitude of its impact, though, is substantially smaller than that of a boycott. When comparing the size of the coefficients, the impact of boycotts on turnout is twice higher than that of violence.

Many of the controls behave according to findings in previous works. Regarding the socioeconomic variables, the results indicate that, population size is negatively correlated with turnout. There is also significant relationship with economic development: the wealthier the 
country, the higher the turnout. There is no strong influence of population heterogeneity on turnout. On the political front, the results show that turnout is higher when the office of the incumbent was being contested in the election. This grants some support to the rewardpunishment logic mentioned earlier. We do not find definitive evidence about the competitiveness of the election. The coefficient on competitiveness is significant in each model by its own and is always negative (as expected, the higher the difference between the first and the second party reduces turnout) but it is no longer significant when included with all the variables simultaneously.

Regarding institutional explanations, neither parliamentary elections have higher turnout than presidential ones, nor is proportional electoral formula associated with a difference in turnout. ${ }^{6}$ In contrast, when elections are concurrent turnout is higher. The most important institutional variables, however, is compulsory voting: in countries with compulsory voting (and controlling for other variables), turnout is on average five percentage points higher agreeing with previous works (Blais 2006). It should be noted furthermore that, due to different degrees of development, the democracies included in our analysis vary in their enforcement capacity. While Australia has an effective bureaucracy and penalty for failure to vote, other countries may not have such capacity. That the coefficient on compulsory voting remains significant across all model specifications despite the wide variation of enforcement capacity testifies to its importance. Moreover, in countries with high enforcement capacity such as Australia, the magnitude of the effect can be expected to be much larger. ${ }^{7}$

\section{Robustness checks}

Table 2 presents the results of two robustness checks. The first, shown in Model 5, introduces a lag of the dependent variable. As discussed in the previous section, previous turnout, as reflected by this lag term, can be an important variable (Aldrich et al. 2011), but is not included in the main model. Because the lag absorbs their explaining power, relatively time-

\footnotetext{
${ }^{6}$ Although we do not report it, we also run the models with a dummy of majoritarian electoral systems and without any variable accounting for the electoral systems. The results were virtually the same.

${ }^{7}$ As an additional robustness check, we ran an analysis excluding the 23 Australian elections. The coefficients remain significant despite smaller magnitude. The result of this analysis is available upon request.
} 
invariant variables such as population size or compulsory voting saw their coefficients greatly reduced in magnitude. These variables, however, retain their statistical significance.

\section{[TABLE 2 ABOUT HERE]}

As a further robustness check, Models 6 and 7 select countries into the sample using a different definition of democracy, namely the combined Freedom House-imputed Polity IV measure by Hadenius and Teorell (2005). Unlike Cheibub et al.’s measure (2010), this variable uses a more inclusive definition of democracy and take into account qualitative aspects such as political and civil liberties (Freedom House) or constraints on executive (Polity IV). Although it is a continuous variable, we follow Wahman et al (2013) and establish a cut-off point of seven, which we use for Model 6. Model 7 is more conservative and uses a threshold of 7.5, which match Hadenius and Teorell's (2007) original dataset.

The robustness checks offer strong evidence to be confident in our findings. Coefficients on all four variables of interest preserve their sign across three additional models, although violence loses its significance. Consistent with Model 4, the harassment of opposition parties’ is positively correlated and statistically significant with turnout in all models.

In the case of banning opposition parties, only the inclusion of previous turnout strips this variable of its significance. It should be noted, however, that previous turnout is a very strict control, and should not be seen as a definitive refutation of banning's impact. Indeed, in the next robustness checks the variable is again positive and significant.

Regarding boycott and violence, we observe two patterns. Previous turnout reduces the magnitude of boycott effects on electoral integrity but do not diminish their significance. Also, boycotting reduces turnout with the more inclusive definition of democracy. Violence, however, ceases to be significant, though point into the same direction. This difference is basically due to the countries included in the sample: while in the initial definition - from 
Cheibub et al - includes 85 countries while the second - from Wahman's et al - is more inclusive (94) and also considers democracies other states such as Lesotho or Namibia.

Table 3 presents the final set of robustness checks. As summary statistics reveal, a concentration of three out of four dependent variables (opposition banning, boycott, and violence) in Latin America and in the post-Cold War period, we set out to include regional and era dummies to verify whether our findings simply mask regional and temporal differences. Thus Model 8 shows the regression coefficients after the inclusion of regional dummies, Model 9 includes era dummies, while Model 10 accounts for both regional and era dummies. These models show little difference when compared to Model 4.

\section{[TABLE 3 ABOUT HERE]}

Finally, in table 3, models 11 to 13, we include two more robustness checks. Model 11 introduces the impact of corruption. Corruption and electoral integrity may go hand in hand and, therefore, its inclusion as a control is compulsory. Stockemer et al (2013) find that countries that are most successful in controlling corruption have higher turnout rates. The impact of corruption with the same measure - International Country Risk Guide (ICRG) - is as strong as found in Stockemer et al (2013), a result that has been confirmed also by Martinez i Coma (2016). More importantly for the purpose of this article, all the significant relations of the variables of interest hold except for boycott. This result is not surprising as, the more corrupt a country is, the less importance is given to its elections, and consequently, the less likely it is that opposition parties decide to boycott. The other control (model 12) introduces a variable measuring the quality of democracy. As we have initially noted, in the analysis we only include democracies. But democracies differ in their quality. Hence, we include a continuous variable accounting for the quality of democracy - from Freedom House and Polity. As model 12 shows, once the country is a democracy, the higher its quality, the lower the turnout. However, when considered jointly with corruption, quality of democracy loses its significance. Nevertheless, the electoral integrity variables hold as in the previous models. 
Overall, the five robustness check models show results that are consistent with our main findings. Barring some differences in magnitudes, the regression coefficients of these models agree with our main model in both direction and significance. This agreement applies for the four electoral integrity variables as well as the host of control variables. Robust to other specification, our model thus presents results that are highly reliable and thus are a contribution to existing literature.

\section{Conclusion}

In this paper we address whether and how electoral integrity affects turnout. We propose a simple framework to study electoral integrity by separating flawed elections from those less problematic through government actions, the opposition actions and the context in which such behaviours happen.

Overall, the results indicate the relevance of electoral integrity as a factor to consider when explaining turnout: when election dynamics imply violation of integrity, turnout is affected. As the analysis and the respective robustness checks show, the actions of the government and the opposition, as well as the environment in which these take place that may affect the integrity of the election and its impact on turnout is evident. Concretely, when in democracies the government bans (some) opposition parties and when the opposition is harassed, turnout increases. Moreover, when the opposition boycotts and when there is a violent context, turnout decreases. However, in democracies, the impact of boycotts is higher than of violence.

Our paper complements two strands of the academic literature and has impact on the public sphere. First, we complement previous studies on turnout by introducing new factors that must be considered in the analysis to accomplish a more detailed picture. In other words, forthcoming turnout models should consider electoral integrity factors as relevant variables. 
Second, our results add to previous studies on turnout and electoral integrity which have focused at the individual level (Birch 2010). The relevance and implications of the findings are straightforward, especially for newer democracies and for practitioners and policy makers when implementing turnout campaigns. As mentioned above, for example, the impact of a boycott in a young democracy may seriously hinder its legitimacy. Hence, by learning which manifestations of electoral integrity violations affect turnout, international organisations can be more efficient in their efforts to strengthen civic participation.

This paper, however, is not without caveats. As the first step towards the inclusion of electoral integrity in the turnout literature, we have set our focus only on democracies. A further analysis of non-democracies as the factors pointed out in the analysis may also be observed in such contexts would be beneficial. Before this could be done, however, better theories need to be developed to account for what could be entirely different mechanisms of political representation. Arguably, democracies share more common elements among themselves than with anocracies and autocracies, which means that present theories on turnout in democracies may not apply to non-democracies.

Future extensions of this work may depart from some of its limitations. For instance, if the literature succeeds in producing sound theories for political representation in nondemocracies, it would be possible to expand this paper's framework analysis into these regimes. A second possibility could be to consider more detailed strategies both from the government and the opposition, or detailed accounts of the different electoral strategies that may emerge in some clientelistic settings (Gans-Morse, Mazzuca and Nichter 2014). It would also be worthwhile to explore the behaviour of other actors such as international and national organisations, such as international observers or independent Election Mission Bodies.

Finally, electoral integrity contributes to understanding turnout not only in the additive sense. If, as has been shown in developing countries, elections only discipline economic policy conditional upon being well conducted (Chauvet and Collier 2009), electoral integrity works also as a modifier for existing variables that could be modelled through interaction or mediation effects. This could be an interesting direction for future research, albeit one that requires a methodology much different from this paper. 


\section{References}

Achen, C. 2001. Why lagged dependent variables can suppress the explanatory power of other independent variables. Annual Meeting of the Political Methodology Section of the American Political Science Association.

Aldrich, J., Montgomery, J. and Wood W. 2011. Turnout as a habit. Political Behavior 33(4): 535-63.

Alesina, A., Devleeschauwer, A., Easterly, W., Kurlat, S., and Wacziarg, R. 2003. Fractionalization. Journal of Economic Growth 8(2): 155-94.

Alvarez, M. R., Hall, T. E., Llewellyn, M. H. 2008. Are Americans confident their ballots are counted? The Journal of Politics 70(3): 754-66.

British Broadcasting Corporation. 2009. Ghana vote despite party boycott. British Broadcasting Corporation URL: <http://news.bbc.co.uk/2/hi/africa/7807448.stm>. Consulted 28 March 2014.

Birch, S. 2010. Perceptions of electoral fairness and voter turnout. Comparative Political Studies 43(12): 1601-22.

Blais, A., and Carty, R. K., 1990. Does proportional representation foster voter turnout? European Journal of Political Research 18: 167-81. 
Blais, A., and Dobrzynska, A. 1998. Turnout in electoral democracies. European Journal of Political Research 33(2): 239-61.

Blais, A. 2006. What affects voter turnout? Annual Review of Political Science 9: 111-25.

Bolt, J. and van Zanden, J. L. 2013. The first update of the Maddison project re-estimating growth before 1820. Maddison-Project Working Paper 4.

Carreras, M. and Irepoglu, Y. 2013. Trust in elections, vote buying, and turnout in Latin America. Electoral Studies 32(4): 609-19.

Chauvet, L. and Collier, P. 2009. Elections and economic policy in developing countries. Economic Policy 24(59):_509-50.

Cheibub, J. A., Gandhi, J. and Vreeland, J. R. 2010. Democracy and dictatorship revisited. Public Choice, 143:67-101.

Collier, P. and Vicente, P.C. 2014. Votes and violence: Evidence from a field experiment in Nigeria. The Economic Journal 124(574): F327-F355.

Donno, D. and Roussias, N. 2012. Does cheating pay? The effect of electoral misconduct on party systems. Comparative Political Studies 45(5): 575-605.

Gans-Morse, J., Mazzuca, S. and Nicther, S. 2014. Varieties of clientelism: machine politics during elections. American Journal of Political Science 58(2): 415-32. 
Galvan, D. 2009. The presidential and parliamentary elections in Senegal, February and June 2007. Electoral Studies 28: 492-517.

García, M. 2009. Political violence and electoral democracy in Colombia: participation and voting behavior in violent contexts. Pittsburgh: University of Pittsburgh.

Geys, B. 2006. Voter turnout: A review of aggregate-level research. Electoral Studies 25(4): 637-63.

Gleditsch, K.S. 2002. Expanded trade and GDP data. Journal of Conflict Resolution 46: 71224.

Golder, M. 2005. Democratic electoral systems around the world, 1946-2000. Electoral Studies 24: 103-21.

Hadenius, A. and Teorell, J. 2007. Pathways from authoritarianism. Journal of Democracy 18(1): 143-57.

Hadenius, A. and Teorell, J. 2005. Assessing alternative indices of democracy. Political Concepts Committee on Concepts and Methods Working Paper Series 6. Centro de Investigacion y Docencia Economicas (CIDE), Mexico

Hafner-Burton, E. M., Hyde, S. and Jablonski R. 2014. When do governments resort to election violence? British Journal of Political Science 44(1): 149-79. 
Hoffman, B. and Robinson, L. 2009. Tanzania's missing opposition. Journal of Democracy 20(4): 123-36.

Hyde, S. D. and Marinov, N. 2012. Which elections can be lost? Political Analysis 20(2): 191-201.

Kang, W. 1998. The rise of a third party in South Korea: the Unification National Party in the 1992 National Assembly election. Electoral Studies 17: 95-110.

Kofie Daddieh, C. 2009. The presidential and parliamentary elections in Ghana, December 2008. Electoral Studies 28: 642-73.

Kuhn, P. 2013. Ethnic voting, partisanship, and pre-electoral violence: evidence from SubSaharan Africa. Workshop on Electoral Integrity, American Political Science Association Conference. 28 August, Chicago.

Lindberg, S. 2006. Democracy and elections in Africa. Baltimore: JHU Press.

IDEA. 2014. Voter Turnout. International Institute for Democracy and Electoral Assistance (IDEA). URL: <http://www.idea.int/vt/index.cfm>. Consulted 28 March 2014.

Martinez i Coma, F. 2016. Turnout determinants in democracies and in non-democracies. Electoral Studies 41: 50-59. 
McCann, J. A. and Domínguez, J. I. 1998. Mexicans react to political fraud and corruption: An assessment of public opinion and voting behavior. Electoral Studies 17(4): 483503.

Nohlen D., Krennerich, M. and Thibaut, B. 1999. Elections in Africa: A Data Handbook. Oxford: Oxford University Press.

Nohlen, D., Grotz, F. and Hartmann, C. 2001. Elections in Asia and the Pacific: A data handbook. Vol. I: Middle East, Central Asia, and South Asia. Oxford: Oxford University Press.

Nohlen, D., Grotz, F. and Hartmann, C. 2001. Elections in Asia and the Pacific: A data handbook. Vol. II: South East Asia, East Asia, and the South Pacific. Oxford: Oxford University Press.

Nohlen, D. 2005. Elections in the Americas: a data handbook. Vol. I: North America, Central America, and the Caribbean. Oxford: Oxford University Press.

Nohlen, D. 2005. Elections in the Americas: a data handbook. Vol. II: South America, Oxford: Oxford University Press.

Norris, P. 2011. Democratic deficit. Cambridge: Cambridge University Press.

Norris, P. 2014. Why electoral integrity Matters. Cambridge: Cambridge University Press. 
OSCE/ODIHR. 2007. Republic of Uzbekistan Presidential Election. 23 December 2007

Limited Election Observation Mission Final Report. OSCE/ODIHR. URL:

<http://www.osce.org/odihr/elections/uzbekistan/31600?download=true>. Consulted 23 June 2016.

Noticias Juridicas. 2002. Ley Orgánica 6/2002, de 27 de junio, de Partidos Políticos (Organic Law of Political Parties). Noticias Juridicas. URL:

$<$ http://noticias.juridicas.com/base_datos/Admin/lo6-2002.html>. Consulted 28 March 2014.

Pedahzur, A. and Perliger, A. 2004. An alternative approach for defining the boundaries of 'party families': Examples from the Israeli Extreme Right-Wing Party Scene. Australian Journal of Political Science 39(2): 285-305.

Robbins, J., Hunter, L. and Murray, G. 2013. Voters versus terrorists: Analyzing the effect of terrorist events on voter turnout. Journal of Peace Research 50(4): 495-508.

Sagás, E. 1997. The 1996 presidential elections in the Dominican Republic. Electoral Studies 16(1): 103-07.

Schedler, A. 2002. The nested game of democratization by elections. International Political Science Review 23(1): 103-22.

Schedler, A. 2012. Judgment and measurement in political science. Perspectives on Politics 10(1): 21-36. 
Simpser, A. 2012. Does electoral manipulation discourage voter turnout? Evidence from Mexico. The Journal of Politics 74(3): 782-95.

Solt, F. 2008. Economic Inequality and democratic political engagement. American Journal of Political Science 52(1): 48-60.

Steiner, N.D. 2010. Economic globalization and voter turnout in established democracies. Electoral Studies 29(3): 444-59.

Stockemer, D., LaMontagne, B. and Scruggs, L. 2013. Bribes and ballots: The impact of corruption on voter turnout in democracies. International Political Science Review 34(1): 74-90.

Teorell, J., Charron, N., Dahlberg, S., Holmberg, S., Rothstein, B., Sundin, P. and Svensson, R. 2013. The Quality of Government Dataset, version 30Apr13. University of Gothenburg: The Quality of Government Institute. URL: <http://www.qog.pol.gu.se>. Consulted 20 March 2014.

Trelles, A. and Carreras M. 2012. Bullets and votes: violence and electoral participation in Mexico. Journal of Politics in Latin America 4(2): 89-123.

Wahman, M., Teorell, J. and Hadenius, A. 2013. Authoritarian regime types re-visited: updated data in comparative perspective. Contemporary Politics 19(1): 19-34. 


\begin{tabular}{|c|c|c|c|c|}
\hline Variables & (1) & (2) & (3) & (4) \\
\hline Log population & $\begin{array}{c}-3.718^{* * * *} \\
(0.619)\end{array}$ & $\begin{array}{c}-3.017 * * * \\
(0.765)\end{array}$ & $\begin{array}{c}-2.519 * * * \\
(0.874)\end{array}$ & $\begin{array}{c}-2.580 * * * \\
(0.835)\end{array}$ \\
\hline Log GDP & $\begin{array}{c}2.110 * * * \\
(0.664)\end{array}$ & $\begin{array}{l}1.484^{* *} \\
(0.751)\end{array}$ & $\begin{array}{l}1.292 * \\
(0.769)\end{array}$ & $\begin{array}{l}1.372 * \\
(0.763)\end{array}$ \\
\hline $\begin{array}{l}\text { Population } \\
\text { heterogeneity }\end{array}$ & -1.462 & -1.096 & -1.917 & -1.430 \\
\hline & (4.339) & $(4.514)$ & (4.385) & $(4.290)$ \\
\hline Election type & $\begin{array}{c}4.195 \\
(3.022)\end{array}$ & $\begin{array}{c}3.866 \\
(2.909)\end{array}$ & $\begin{array}{c}3.587 \\
(2.991)\end{array}$ & $\begin{array}{c}4.129 \\
(3.017)\end{array}$ \\
\hline Compulsory voting & $\begin{array}{c}6.620 * * * \\
(1.945)\end{array}$ & $\begin{array}{c}6.743 * * * \\
(2.062)\end{array}$ & $\begin{array}{c}7.504^{* * *} \\
(1.912)\end{array}$ & $\begin{array}{c}6.838 * * * \\
(2.049)\end{array}$ \\
\hline PR & $\begin{array}{c}0.927 \\
(1.404)\end{array}$ & $\begin{array}{c}1.123 \\
(1.463)\end{array}$ & $\begin{array}{l}-0.272 \\
(1.444)\end{array}$ & $\begin{array}{c}0.660 \\
(1.407)\end{array}$ \\
\hline Concurrent election & $\begin{array}{c}5.309 * * * \\
(1.174)\end{array}$ & $\begin{array}{c}4.872 * * * \\
(1.233)\end{array}$ & $\begin{array}{c}4.606 * * * \\
(1.167)\end{array}$ & $\begin{array}{c}5.043 * * * \\
(1.136)\end{array}$ \\
\hline Incumbent running & $\begin{array}{c}7.718 * * * \\
(2.250)\end{array}$ & $\begin{array}{c}7.488 * * * \\
(2.064)\end{array}$ & $\begin{array}{c}7.871 * * * \\
(2.220)\end{array}$ & $\begin{array}{c}7.794 * * * \\
(2.256)\end{array}$ \\
\hline Competitiveness & $\begin{array}{c}-0.0865 * * * \\
(0.0335)\end{array}$ & $\begin{array}{l}-0.0614 * \\
(0.0326)\end{array}$ & $\begin{array}{c}-0.0937 * * * \\
(0.0336)\end{array}$ & $\begin{array}{l}-0.0494 \\
(0.0318)\end{array}$ \\
\hline Opposition harassment & $\begin{array}{c}3.613 * * * \\
(1.306)\end{array}$ & & & $\begin{array}{c}5.459 * * * \\
(1.317)\end{array}$ \\
\hline Opposition ban & $\begin{array}{l}3.146 * * \\
(1.562)\end{array}$ & & & $\begin{array}{l}3.717 * * \\
(1.668)\end{array}$ \\
\hline Boycott & & $\begin{array}{c}-6.172 * * * \\
(1.518)\end{array}$ & & $\begin{array}{c}-7.198 * * * \\
(1.667)\end{array}$ \\
\hline Violence & & & $\begin{array}{c}-2.107^{*} \\
(1.265)\end{array}$ & $\begin{array}{c}-3.197 * * \\
(1.355)\end{array}$ \\
\hline Constant & $\begin{array}{c}70.13 * * * \\
(6.851)\end{array}$ & $\begin{array}{c}71.06^{* * *} \\
(7.125)\end{array}$ & $\begin{array}{c}69.96 * * * \\
(7.138)\end{array}$ & $\begin{array}{c}67.66^{* * * *} \\
(6.721)\end{array}$ \\
\hline Observations & 717 & 717 & 721 & 716 \\
\hline Number of countries & 85 & 85 & 85 & 85 \\
\hline Years & $1950-2008$ & & & \\
\hline R-squared & 0.919 & 0.912 & 0.915 & 0.917 \\
\hline
\end{tabular}




\begin{tabular}{|c|c|c|c|c|}
\hline Variables & (4) & (5) & (6) & (7) \\
\hline Log population & $\begin{array}{c}-2.580 * * * \\
(0.835)\end{array}$ & $\begin{array}{c}-0.516 \\
(0.484)\end{array}$ & $\begin{array}{c}-3.582 * * * \\
(1.067)\end{array}$ & $\begin{array}{c}-2.979 * * * \\
(1.081)\end{array}$ \\
\hline Log GDP & $\begin{array}{l}1.372^{*} \\
(0.763)\end{array}$ & $\begin{array}{l}-0.105 \\
(0.394)\end{array}$ & $\begin{array}{c}2.576^{* * *} \\
(0.751)\end{array}$ & $\begin{array}{l}1.749 * * \\
(0.748)\end{array}$ \\
\hline $\begin{array}{l}\text { Population } \\
\text { heterogeneity }\end{array}$ & $\begin{array}{l}-1.430 \\
(4.290)\end{array}$ & $\begin{array}{l}-0.233 \\
(2.158)\end{array}$ & $\begin{array}{c}2.839 \\
(4.279)\end{array}$ & $\begin{array}{l}-0.345 \\
(4.193)\end{array}$ \\
\hline Election type & $\begin{array}{c}4.129 \\
(3.017)\end{array}$ & $\begin{array}{c}6.161^{* * *} \\
(1.164)\end{array}$ & $\begin{array}{c}7.313^{* * *} \\
(2.125)\end{array}$ & $\begin{array}{c}8.572 * * * \\
(2.229)\end{array}$ \\
\hline Compulsory voting & $\begin{array}{c}6.838 * * * \\
(2.049)\end{array}$ & $\begin{array}{c}4.085^{* * *} \\
(1.198)\end{array}$ & $\begin{array}{c}8.576^{* * *} \\
(1.521)\end{array}$ & $\begin{array}{c}8.478^{* * *} \\
(1.729)\end{array}$ \\
\hline PR & $\begin{array}{c}0.660 \\
(1.407)\end{array}$ & $\begin{array}{l}1.385^{*} \\
(0.749)\end{array}$ & $\begin{array}{c}1.986 \\
(1.320)\end{array}$ & $\begin{array}{c}0.444 \\
(1.593)\end{array}$ \\
\hline Concurrent election & $\begin{array}{c}5.043 * * * \\
(1.136)\end{array}$ & $\begin{array}{c}4.077^{* * *} \\
(1.199)\end{array}$ & $\begin{array}{c}6.615^{* * *} \\
(1.033)\end{array}$ & $\begin{array}{c}7.158^{* * *} \\
(0.919)\end{array}$ \\
\hline Incumbent running & $\begin{array}{c}7.794 * * * \\
(2.256)\end{array}$ & $\begin{array}{c}7.138 * * * \\
(1.073)\end{array}$ & $\begin{array}{c}6.830 * * * \\
(1.651)\end{array}$ & $\begin{array}{c}6.986 * * * \\
(1.636)\end{array}$ \\
\hline Competitiveness & $\begin{array}{c}-0.0494 \\
(0.0318)\end{array}$ & $\begin{array}{c}-0.0641^{* *} \\
(0.0319)\end{array}$ & $\begin{array}{c}0.0682 * * * \\
(0.0257)\end{array}$ & $\begin{array}{c}0.0731^{* *} \\
(0.0329)\end{array}$ \\
\hline Previous turnout & & $\begin{array}{c}0.608^{* * *} \\
(0.0494)\end{array}$ & & \\
\hline Opposition harassment & $\begin{array}{c}5.459 * * * \\
(1.317)\end{array}$ & $\begin{array}{l}3.393^{* *} \\
(1.418)\end{array}$ & $\begin{array}{c}3.943 * * * \\
(1.429)\end{array}$ & $\begin{array}{l}4.311^{* *} \\
(1.809)\end{array}$ \\
\hline Opposition ban & $\begin{array}{c}3.717^{* *} \\
(1.668)\end{array}$ & $\begin{array}{c}2.288 \\
(1.466)\end{array}$ & $\begin{array}{c}3.338^{* *} \\
(1.612)\end{array}$ & $\begin{array}{c}3.692^{* *} \\
(1.742)\end{array}$ \\
\hline Boycott & $\begin{array}{c}-7.198^{* * *} \\
(1.667)\end{array}$ & $\begin{array}{l}-3.563^{*} \\
(1.823)\end{array}$ & $\begin{array}{c}-5.655^{* * *} \\
(1.553)\end{array}$ & $\begin{array}{c}-6.836^{* * *} \\
(1.679)\end{array}$ \\
\hline Violence & $\begin{array}{c}-3.197 * * \\
(1.355)\end{array}$ & $\begin{array}{l}-1.867 \\
(1.153)\end{array}$ & $\begin{array}{l}-1.873 \\
(1.258)\end{array}$ & $\begin{array}{c}-1.160 \\
(1.630)\end{array}$ \\
\hline Constant & $\begin{array}{c}67.66^{* * *} \\
(6.721)\end{array}$ & $\begin{array}{c}20.72^{* * * *} \\
(5.016)\end{array}$ & $\begin{array}{c}57.23 * * * \\
(6.471)\end{array}$ & $\begin{array}{c}61.24 * * * \\
(5.334)\end{array}$ \\
\hline Observations & 716 & 672 & 750 & 709 \\
\hline Number of countries & 85 & 82 & 94 & 90 \\
\hline Years & $1950-2008$ & & & \\
\hline R-squared & 0.917 & 0.943 & 0.906 & 0.911 \\
\hline
\end{tabular}

Standard errors in parentheses ${ }^{* * *} \mathrm{p}<0.01,{ }^{* *} \mathrm{p}<0.05,{ }^{*} \mathrm{p}<0.1$ 


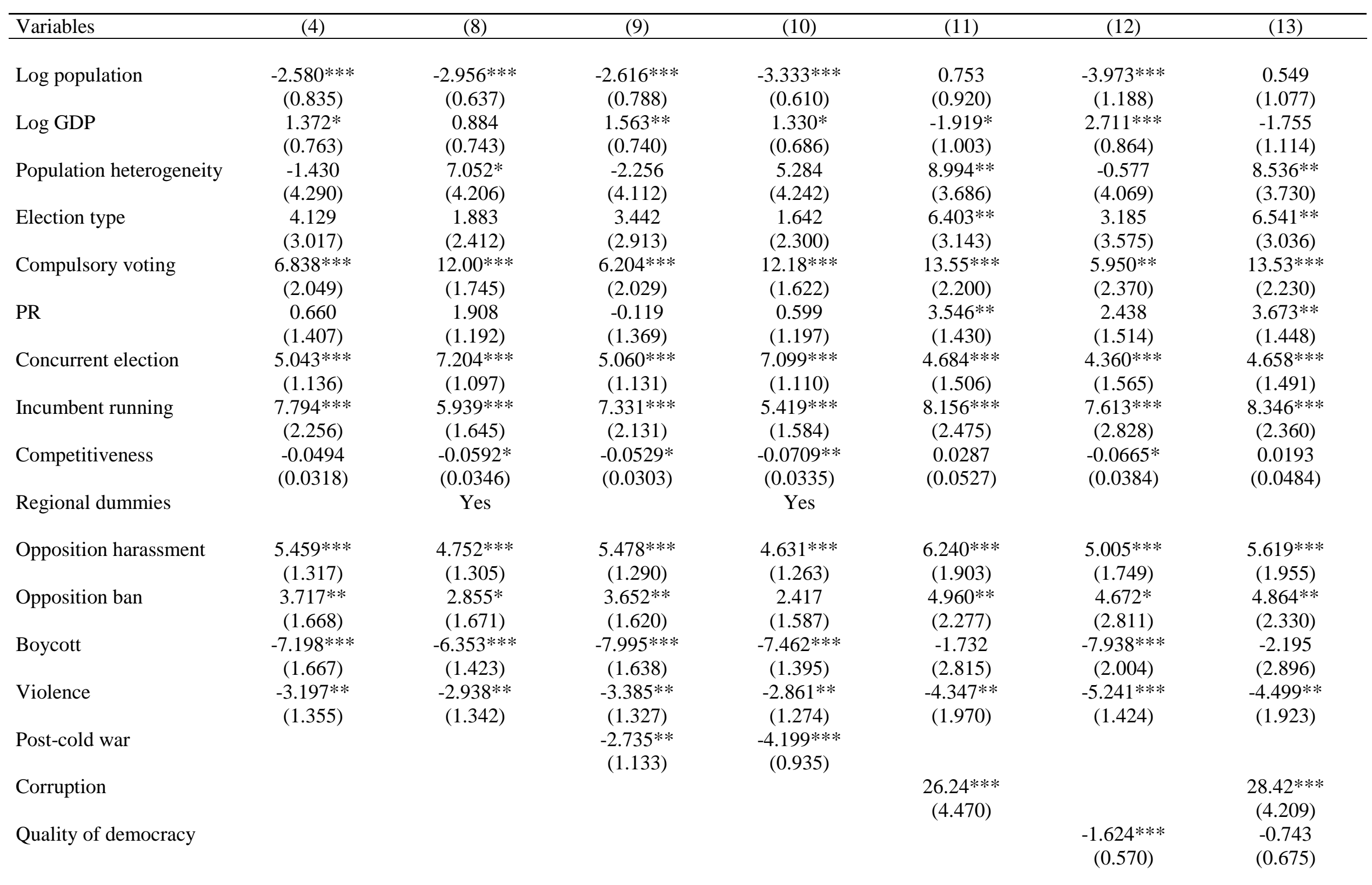




\begin{tabular}{|c|c|c|c|c|c|c|c|}
\hline Constant & $\begin{array}{c}67.66 * * * \\
(6.721)\end{array}$ & $\begin{array}{c}83.51 * * * \\
(6.472)\end{array}$ & $\begin{array}{c}69.33 * * * \\
(6.619)\end{array}$ & $\begin{array}{c}86.62 * * * \\
(6.141)\end{array}$ & $\begin{array}{c}47.03 * * * \\
(5.738)\end{array}$ & $\begin{array}{c}79.98 * * * \\
(9.738)\end{array}$ & $\begin{array}{c}52.23 * * * \\
(8.087)\end{array}$ \\
\hline Observations & 716 & 713 & 716 & 713 & 413 & 545 & 413 \\
\hline Number of countries & 85 & 84 & 85 & 84 & 77 & 85 & 77 \\
\hline Years & $1950-2008$ & & & & 1984-2008 & $1972-2008$ & 1984-2008 \\
\hline R-squared & 0.917 & 0.924 & 0.924 & 0.932 & 0.936 & 0.921 & 0.934 \\
\hline
\end{tabular}

